\title{
The Role of CAR, NPL, and LDR Towards Profitability Banking to Registered Banks in Indonesia Stock Exchange Period 2012-2016
}

\author{
Purwanto $^{1}$, Misti Hariasih ${ }^{2}$, Rizky Eka Febriansah \\ purwaloveis@gmail.com ${ }^{1}$ \\ Universitas Muhammadiyah Sidoarjo, Indonesia ${ }^{1}$
}

\begin{abstract}
This study aims to determine the effect of CAR,NPL, and LDR Against Banking Profitability proxied with ROA at Commercial Banks Listed on BEI either partially or simultaneously. The type of this research is quantitative research. Population in this research is Commercial Bank resgistered in BEI period 2012-2016. The technique of determining the sample in this study using purposive sumpling, so that obtained 7 commercial banks consisting of state-owned banks and private-owned banks. Data analysis techniques were performed using descriptive statistical analysis and multiple liniear regression analysis. The results of this syudy indicate that in Commercial Banks Listed on BEI period 2012-2016 partially CAR have positive and significant effect on ROA, and LDR have positive and significant effect to ROA, while NPL have negative and significant effect to ROA. Simultaneously CAR, NPL, and LDR have a significant effect on ROA.
\end{abstract}

Keywords: Capital Adequacy Ratio (CAR); Non Performing Loan (NPL); Loan Deposit to Ratio (LDR) and Return On Asset (ROA).

\section{Pendahuluan}

Dewasa ini perkembangan dunia perbankan semakin pesat dan modern, baik dari segi ragam produk, kualitas pelayanan, maupun teknologi yang dimiliki. Perbankan semakin mendominasi perkembangan ekonomi dan bisnis suatu negara. Bahkan aktivitas perbankan dan keberadaan perbankan sangat menentukan kemajuan suatu negara dalam bidang ekonomi. Apabila perbankan suatu negara hancur, maka akan mengakibatkan kehancuran perekonomian suatu negara yang bersangkutan seperti yang terjadi di Indonesia pada tahun1998 dan 1999 [1].

Tingkat kesehatan bank merupakan unsur yang penting dalam dunia perbankan untuk keberlangsungan hidup sebuah lembaga perbankan. Kesehatan suatu bank merupakan kemampuan bank dalam melakukan kegiatan operasional perbankan secara normal dan mampu dapat memenuhi semua kewajibannya dengan baik sesuai dengan perarturan perbankan yang berlaku [2]. Salah satu cara menentukan tingkat kesehatan kinerja keuangan suatu bank adalah dengan mengukur kinerja profitabilitas bank. Penilaian ROA lebih dipentingkan dari pada ROE oleh Bank Indonesia dalam menentukan kesehatan bank, karena Bank Indonesia lebih mengutamakan nilai profitabilitas suatu bank yang diukur dengan asset yang dananya sebagian besar berasal dari dana simpanan masyarakat sehingga ROA lebih mewakili dalam mengukur tingkat profitabilitas perbankan [3].

Berdasarkan ketentuan Bank Indonesia, beberapa faktor yang dapat berpengaruh terhadap ROA adalah Capital 
Adequacy Ratio (CAR), Non Perfoming Loan (NPL), dan Loan to Deposit Ratio (LDR).Capital Adequacy Ratio (CAR) adalah rasio kewajiban pemenuhan modal minimum yang harus dimiliki oleh Bank [4]. Data Rata-rata nilai CAR, NPL, LDR dan ROA pada tahun 2012-2016 dapat dilihat pada tabel 1.

Tabel 1 CAR, NPL, LDR, ROA pada bank umum

\begin{tabular}{|l|l|l|l|l|l|}
\hline \multirow{2}{*}{ Rasio } & \multicolumn{5}{|l|}{ Tahun } \\
\cline { 2 - 6 } & 2012 & 2013 & 2014 & 2015 & 2016 \\
\hline CAR (\%) & 17,43 & 18,13 & 19,57 & 21,39 & 22,93 \\
\hline NPL (\%) & 1,31 & 1,42 & 1,20 & 1,83 & 2,02 \\
\hline LDR (\%) & 83,58 & 89,70 & 89,42 & 92,11 & 90,70 \\
\hline ROA (\%) & 3,11 & 3,08 & 2,85 & 2,32 & 2,23 \\
\hline
\end{tabular}

Sumber : B. Indonesia [5]

Berdasarkan tabel di atas peneliti mengamati bahwa variabel CAR, NPL, dan LDR terdapat hubungan yang tidak konsisten terhadap ROA. Menurut teori apabila CAR dan LDR naik maka ROA juga mengalami kenaikan, sedangkan apabila NPL naik maka ROA mengalami penurunan. Pada data diatas menyebutkan sebaliknya, sehingga perlu dilakukan pengujian untuk membuktikan teori tersebut. Beberapa penelitian terdahulu tentang rasio-rasio yang mempengaruhi profitabilitas perbankan (ROA), terdapat ketidak sesuaian hasil atau Research Gap salah satunya penelitia yang dilakukan oleh Muttaqin [6] menyatakan bahwa CAR dan NPL berpengaruh positif tidak signifikan terhadap ROA dan LDR berpengaruh negatif tidak signifikan terhadap ROA. Sedangkan penelitian yang sesuai dengan teori-teori dalam penelitian ini adalah penelitian yang dilakukan oleh Kurniasih [7] menyatakan bahwa CAR dan LDR berpengaruh positif signifikan terhadap ROA dan NPL berpengaruh negatif signifikan terhadap ROA. Maka dari penjelasan diatas penulis tertarik melakukan penelitian mengenai rasio yang mempengaruhi profitabilitas. perbankan dengan judul "PENGARUH CAR, NPL, DAN LDR TERHADAP PROFITABILITAS PERBANKAN PADA BANK UMUM YANG TERDAFTAR DI BEI PERIODE 2012-2016".

\section{Metode}

Penelitian ini menggunakan pendekatan kuantitaf. Metode penelitian kuantitatif dapat diartikan sebagai metode penelitian yang berdasarkan pada filsafat positivisme, digunakan untuk meneliti pada populasi atau sumpel tertentu, pengumpulan data menggunakan instrument penelitian, analisis data bersifat kuantitatif/statistik, dengan tujuan untuk menguji hipotesis yang telah ditetapkan [8]. Data yang digunakan dalam penelitian ini adalah laporan keuangan perbankan yang terdaftar di bursa efek Indonesia (BEI) periode 2012-2016. Sumber data yang digunakan dalam penelitian ini adalah bank yang sudah dipublikasikan oleh Bursa Efek Indonesia (BEI) Universitas Muhammadiyah Sidoarjo dan situs resmi bursa efek Indonesia www.idx.co.id. Adapun teknik pengambilan sampel dilakukan dengan purposive sampling. Purposive sampling adalah teknik penentuan sampel dengan pertimbingan tertentu [8]. Berikut penggolongan sampel berdasarkan kriteria yang telah ditentukan dapat dilihat pada tabel 2 . 
Tabel 2 Kriteria Sampel Penelitian

\begin{tabular}{|l|l|c|}
\hline No & Kriteria Sampel & Jumlah \\
\hline 1. & Bank umum yang yang terdaftar di BEI periode tahun 2012-2016. & 43 \\
\hline 2. & $\begin{array}{l}\text { Bank umum yang tidak menyajikan Laporan keuangan secara } \\
\text { lengkap dan rasio-rasio yang dibutuhkan dalam penelitian ini } \\
\text { selama 5 tahun berturut-turut. }\end{array}$ & $(20)$ \\
\hline 3. & Perbankan yang tidak memiliki 2 total aset terbesar periode 2016 & $(16)$ \\
\hline 4. & Total & 7 \\
\hline
\end{tabular}

Bank umum yang menjadi kriteria pada penelitian ini sebanyak 7 bank yang dapat dilihat pada tabel 3.

Tabel 3 Daftar nama bank yang menjadi kriteria

\begin{tabular}{|c|c|c|c|c|}
\hline No & Kode Saham & $\begin{array}{l}\text { Segi } \\
\text { Kepemilikan }\end{array}$ & Emiten Perbankan & $\begin{array}{l}\text { Total Aset } \\
\text { (dalam jutaan } \\
\text { Rupiah) }\end{array}$ \\
\hline 1. & BMRI & \multirow[t]{3}{*}{$\begin{array}{l}\text { Bank Milik } \\
\text { Pemerintah }\end{array}$} & Bank Mandiri Persero Tbk. & 1.038 .706 .009 \\
\hline 2. & BBRI & & Bank Rakyat Indonesia Tbk. & 1.003 .644 .426 \\
\hline 3. & BJBR & & $\begin{array}{l}\text { Bank Pembangunan Daerah } \\
\text { Jawa Barat dan Banten Tbk. }\end{array}$ & 102.318 .457 \\
\hline 4. & BNGA & \multirow[t]{4}{*}{$\begin{array}{ll}\text { Bank } & \text { Milik } \\
\text { Swasta } & \end{array}$} & Bank CIMB Niaga Tbk. & 238.849 .252 \\
\hline 5. & BBCA & & Bank Central Asia Tbk. & 662.594 .586 \\
\hline 6. & MEGA & & Bank MEGA Tbk. & 70.528 .785 \\
\hline 7. & BBYB & & Bank Yudha Bakti Tbk. & 4.134 .414 \\
\hline
\end{tabular}

Sumber: www.idx.id

\section{Pembahasan}

Data yang digunakan dalam penelitian ini adalah data sekunder. Berdasarkan kriteria yang ditentukan oleh penulis, terdapat 7 bank yang menjadi sampel kemudian di kalikan tahun penelitian yaitu selama 5 tahun sehingga didapatkan total sampel penelitian sebesar 35 data sampel dari data laporan keuangan perbankan yang terdaftar di bursa efek Indonesia (BEI) periode 2012-2016. 
Dalam statistik deskriptif digunakan untuk memberikan gambaran deskripsi data pada tiap variabel penelitian yang di gunakan. Data tersebut meliputi nilai minimum, nilai maksimum, nilai rata-rata (mean) dan standart deviasi. Hasil dari penelitian yang dilakukan secara deskriptif dapat dilihat pada tabel 4 .

Tabel 4 Statistik Diskriptif

\begin{tabular}{|l|l|l|l|l|c|}
\hline & $\mathrm{N}$ & Minimum & Maximum & Mean & Std. Deviation \\
\hline CAR & 35 & 1289,00 & 2291,00 & 1722,4571 & 232,14313 \\
NPL & 35 & 140,00 & 415,00 & 252,0286 & 91,72224 \\
LDR & 35 & 5239,00 & 9647,00 & 8185,3714 & 1050,64700 \\
ROA & 35 & 47,00 & 515,00 & 265,5429 & 133,19653 \\
Valid N & 35 & & & & \\
(listwise) & & & & & \\
& & & & & \\
\hline
\end{tabular}

Sumber: Hasil Output SPSS, data diolah 2018

Berdasarkan hasil penelitian tabel 4.1 dapat diketahui bahwa dari keempat variabel penelitian dapat dilihat masing-masing nilai mean adalah CAR 1722,4571, NPL 252,0286, LDR 8185,3714 , dan ROA 265,5429. Standar deviasi (simpangan baku) digunakan untuk menilai dispersi rata-rata dari sampel yang menunjukkan nilai CAR 232,14313, NPL 91,72224, LDR 1050,64700 dan ROA 133,19653 . Dari data tersebut dapat di simpulkan bahwa rata-rata lebih besar dari pada standar deviasi menunjukkan data dari keempat variabel dalam penelitian ini baik. A. Uji Asumsi Klasik Uji Normalitas

Ghozali [9] menyatakan bahwa uji normalitas bertujuan untuk menguji apakah dalam model regresi, variabel independen dan variabel dependen keduanya mempunyai distribusi normal ataukah tidak.Uji normalitas digunakan untuk menguji apakah dalam model regresi, variabel independen dan variabel dependen keduanya mempunyai distribusi normal ataukah tidak. Uji normalitas data penelitian ini menggunakan uji kolmogorov smirnov. Pengujian data dikatakan normal jika nilai Asymph. Sig. (2-tailed) berada di atas 0,05. Hasil pengujian normalitas dilakukan dengan nonparametric test 1 sample K-S sebagai tabel 5.

Berdasarkan hasil uji normalitas menggunakan uji Kolmogorov-Smirnov, hasil dari pengolahan data menunjukkan bahwa data berdistribusi normal. Hal ini dapat dibuktikan dari hasil uji 1 sampel K-S yang menunjukkan nilai Asymph. Sig. (2-tailed) sebesar 0,901 dan nilai tersebut lebih besar dari $0,05(0,901>0,05)$.

\section{Pengujian Hipotesis}

Pengujian Terhadap Hipotesis

Pengujian terhadap hipotesis penelitian ini di uji menggunakan Uji t (Parsial). Uji t bertujuan untuk menguji seberapa jauh pengaruh satu variabel independent secara individu terhadap variabel dependen debgan melihat nilai profitabilitas. Keputusan uji hipotesis secara parsial dilakukan berdasarkan ketentuan sebagai berikut : 
1) Apabila tingkat signifikansi lebih besar dari 5\%, maka dapat disimpulkan bahwa Ho diterima dan Ha ditolak.

2) Apabila tingkat signifikansi lebih kecil dari 5\%, maka dapat disimpulkan bahwa Ho ditolak dan Ha diterima.

Tabel 5 Uji Normalitas

\begin{tabular}{|ll|r|}
\hline & & Unstandardized Residual \\
\hline $\mathrm{N}$ & & 35 \\
Normal Parametersa,b & Mean &, 0000000 \\
& Std. Deviation & 70,25931563 \\
Most Extreme Differences & Absolute &, 096 \\
& Positive &, 094 \\
& Negative &,- 096 \\
& &, 570 \\
Kolmogorov-Smirnov Z & &, 901 \\
Asymp. Sig. (2-tailed) & &, 0 \\
\hline
\end{tabular}

Tabel 6 Uji t Coefficientsa

\begin{tabular}{|c|c|c|c|c|c|c|c|}
\hline \multirow[t]{2}{*}{ Model } & \multicolumn{2}{|c|}{$\begin{array}{l}\text { Unstandardized } \\
\text { Coefficients }\end{array}$} & \multirow{2}{*}{$\begin{array}{c}\begin{array}{c}\text { Standardized } \\
\text { Coefficients }\end{array} \\
\text { Beta }\end{array}$} & \multirow[b]{2}{*}{$\mathrm{t}$} & \multirow[b]{2}{*}{ Sig. } & \multicolumn{2}{|c|}{ Collinearity Statistics } \\
\hline & B & $\begin{array}{l}\text { Std. } \\
\text { Error }\end{array}$ & & & & Tolerance & VIF \\
\hline 1 (Constant) & 10,684 & 144,734 & &, 074 &, 942 & & \\
\hline CAR &, 185 & 055 & ,323 & 3,397 &, 002 & ,993 & 1,007 \\
\hline NPL & $-1,135$ & 138 &,- 781 & $-8,217$ &, 000 & ,992 & 1,008 \\
\hline LDR &, 027 &, 012 &, 214 & 2,238 &, 033 & ,985 & 1,015 \\
\hline
\end{tabular}

a. Dependent Variable: ROA

Sumber: Hasil Output SPSS, data diolah 2018

CAR memiliki pengaruh positif dan signifikan secara parsial terhadap ROA diperoleh nilai koefisien regresi untuk variabel CAR sebesar 0,323 . Sementara nilai signifikan sebesar 0,002, dimana nilai ini menunjukkan signifikan karena lebih kecil dari 0,05 atau $(0,002<0,05)$ artinya $\mathrm{H} 1$ diterima.

NPL memiliki pengaruh negatif dan signifikan secara parsial terhadap ROA diperoleh nilai koefisien regresi untuk variabel NPL sebesar -0,781. Sementara nilai signifikan sebesar 0,000 dimana nilai ini menunjukkan signifikan karena lebih kecil dari 0,05 atau $(0,000<0,05)$ artinya $\mathrm{H} 1$ diterima. 
LDR memiliki pengaruh positif dan signifikan secara parsial terhadap ROA diperoleh nilai koefisien regresi untuk variabel NPL sebesar 0,214. Sementara nilai signifikan sebesar 0,033 dimana nilai ini menunjukkan signifikan karena lebih kecil dari 0,05 atau $(0,033<0,05)$ artinya $\mathrm{H} 1$ diterima.

Dari hasil uji t menunjukkan bahwa variabel CAR mempunyai pengaruh positif dan signifikan terhadap profitabilitas (ROA) diperoleh nilai koefisien regresi sebesar 0,323. Hasil uji t untuk variabel CAR diperoleh nilai signifikan t hitung sebesar 3,397 dan nilai t tabel sebesar 1,69552 dimana nilai t hitung $>$ nilai $t$ tabel $(3,397>1,69552)$ kemudian nilai signifikan sebesar 0,002, dimana nilai ini menunjukkan signifikan karena lebih kecil dari 0,05 atau $(0,002<0,05)$, maka dapat disimpulkan bahwa CAR berpengaruh positif dan signifikan terhadap ROA pada Bank Umum yang terdaftar di BEI sehingga hipotesis pertama diterima.

Dari hasil uji t menunjukkan bahwa variabel NPL mempunyai pengaruh negatif dan signifikan terhadap profitabilitas (ROA) diperoleh nilai koefisien regresi sebesar -0,781. Hasil uji t untuk variabel NPL diperoleh nilai signifikan t hitung sebesar -8,217 dan nilai t tabel sebesar -1,69552 dimana nilai t hitung $>$ nilai $t$ tabel $(-8,217>1,69552)$ kemudian nilai signifikan sebesar 0,000 , dimana nilai ini menunjukkan signifikan karena lebih kecil dari 0,05 atau $(0,000<0,05)$, maka dapat disimpulkan bahwa NPL berpengaruh negatif dan signifikan terhadap ROA pada Bank Umum yang terdaftar di BEI sehingga hipotesis kedua diterima.

Dari hasil uji t menunjukkan bahwa variabel LDR mempunyai pengaruh positif dan signifikan terhadap profitabilitas (ROA) diperoleh nilai koefisien regresi sebesar 0,214. Hasil uji t untuk variabel LDR diperoleh nilai signifikan t hitung sebesar 2,238 dan nilai t tabel sebesar 1,69552 dimana nilai t hitung $>$ nilai t tabel $(2,238>1,69552)$ kemudian nilai signifikan sebesar 0,033 , dimana nilai ini menunjukkan signifikan karena lebih kecil dari 0,05 atau $(0,033<0,05)$, maka dapat disimpulkan bahwa LDR berpengaruh positif dan signifikan terhadap ROA pada Bank Umum yang terdaftar di BEI sehingga hipotesis ketiga diterima.

Berdasarkan uji F (simultan) di atas, hasil menunjukkan bahwa signifikansi $\mathrm{F}$ hitung sebesar 26,805 dan nilai $\mathrm{F}$ tabel sebesar 2,91 dimana nilai t hitung > nilai t tabel $(2,238>$ $1,69552)$ kemudian nilai signifikan sebesar 0,000 . Berdasarkan nilai signifikan yang jauh lebih kecil dari 0,05, maka dapat dikatakan bahwa CAR, NPL, dan LDR secara bersama-sama berpengaruh signifikan terhadap profitabilitas (ROA) pada Bank Umum yang terdaftar di BEI sehingga hipotesis keempat diterima.

\section{Kesimpulan}

CAR berpengaruh positif terhadap profitabilitas (ROA) pada bank umum yang terdaftar di BEI dengan nilai keofisien sebesar 0,323 dan signifikan sebesar 0,002. Dengan demikian H1 diterima.

NPL berpengaruh negatif terhadap profitabilitas (ROA) pada bank umum yang terdaftar di BEI dengan nilai keofisien sebesar -0,781 dan signifikan sebesar 0,000. Dengan demikian H2 diterima.

LDR berpengaruh positif terhadap profitabilitas (ROA) pada bank umum yang terdaftar di BEI dengan nilai keofisien sebesar 0,214 dan signifikan sebesar 0,033 . Dengan demikian H3 diterima.

CAR, NPL, dan LDR secara bersama-sama berpengaruh terhadap profitabilitas (ROA) pada Bank Umum yang terdaftar di BEI dengan nilai $F$ hitung sebesar 28,805 dengan tingkat signifikan sebesar 0,000. Dengan demikian H4 diterima. 


\section{References}

[1] Kasmir, Manajemen Perbankan. Jakarta: PT Grafindo Graha, 2014.

[2] T. Budisantoso and Nuritmo, Bank dan Lembaga Keuangan Lain. Jakarta: Salemba Empat, 2015.

[3] L. Dendawijaya, Manajemen Perbankan. Jakarta: Ghalia Indonesia, 2001.

[4] S. Riyadi, Banking Asset dan Liability Management. Jakarta: Fakultas Ekonomi Universitas Indonesia, 2006

[5] B. Indonesia, "Statistik perbankan Indonesia," ed, 2016.

[6] H. F. Muttaqin, "Pengaruh CAR, BOPO, NPL dan terhadap ROA pada Bank Konvensional (Studi Kasus pada Bank Konvensional yang terdaftar di BEI)," Jurnal Ilmu dan Riset manajemen, vol. 4, pp. 1229-1240, 2017.

[7] E. Kurniasih, "Pengaruh Capital Adequacy Ratio, Non Performing Loan, To Deposit Ratio,

Efisiensi Operasi, Not Interest Margin Terhadap Return On Aset," Journal Of Accounting, vol. 2, 2016.

[8] Sugiyono, Metode Penelitian Kuantitatif, Kualitatif Dan R \& D. Bandung: Alfabeta, 2011.

[9] I. Ghozali, Aplikasi Analisis Multivarite dengan SPSS. Semarang: Universitas Diponegoro, 2011. 